\title{
Focus on Staff
}

\section{Staff Recognition and Appreciation}

If you want to reward a staff member for a job well-done, nothing beats a big, fat bonus, right?

Wrong. Just ask Shirley Shuster, APRN, BC, OCN, and director of clinical services at Commonwealth Hematology Oncology (CHO), based in Quincy, Massachusetts.

For years, the annual bonus has been part of a year-end recognition for employees at CHO's eight sites, bestowed along with a thank-you note. But this past winter, that little thank-you note got a major rewrite, and the result was a major response.

The missive stated, "Because of your hard work and dedication, our patients and their families have felt cared for in every sense of the word. We appreciate what you do to make $\mathrm{CHO}$ what it is today, a place where we provide compassionate care for the whole person, close to home. Thank you for all you do."

Staffers kept mentioning the message to Shuster- how much it meant to them, how nice it was to read. Why the unprecedented reaction? "It is the words we say that people remember-long after bonuses are spent," she says.

And Shuster appears to be right. Research into corporate reward systems is showing that, though cash is tops on lists of employee-preferred awards, motivation over the long haul takes more than extra money. Publications ranging from the Harvard Business Review to the best-selling "1,001 Ways to Reward Employees" have been documenting other ways by which employees can be urged and encouraged into top performance. The personal touch is key among them.

In "1,001 Ways to Reward Employees," author Bob Nelson, $\mathrm{PhD}$, points out that $95 \%$ of employees regard cash or a cash substitute, such as a gift certificate, as a positive, meaningful incentive. However, praise is also highly valued- $-99.4 \%$ of employees report it is "extremely important, very important, or somewhat important" to receive praise, he states in the book.

But it often doesn't get disseminated the way it should in medical settings. In fact, physicians, according to Nelson, may be among the worst when it comes to imparting praise. Survey results indicate many believe they hand out such kudos very frequently, while their employees say it happens rarely.
Maybe that's because the secret to fostering high performance recently was thought to lie in rewards based on "differentiation," a system popularized by former GE CEO Jack Welch. It divides employees into performance levels, with the most generous rewards reserved for the top percentile. But benchmarking performers and the differentiation process often impede team building, an essential ingredient of successful oncology practices (see sidebar).

This concept takes a page from the past. In the 1944 text Modern Business, a former dean of the New York University School of Business describes "the executive who succeeds" as one who "wastes no time finding fault" and infuses the workforce with positive energy.

This past July, Fortune Magazine weighed in, publishing a cover story that blasted, "Sorry, Jack! Welch's Rules for Winning Don't Work Anymore.” And this coming spring, the Medical Group Management Association will kick off its 2007 executive seminar series with a session by affirmation advocate Kim Cameron, PhD, who is known for his work on positive leadership.

So why isn't a good paycheck enough? That might be the case if a work site was just a place where a salary is earned, observes John E. Hennessy, executive director at the Kansas City Cancer Center (KCCC) in Overland Park, Kansas. But it's not. "It's where you spend half of your waking life," he says.

One secret to getting the most out of people is to make expectations of them plain and simple, he advises. Taking a cue from a family restaurant that posts its goals on a big sign in the kitchen, KCCC's medical offices now all have a classroom-sized whiteboard listing routine tasks. The boards function as a kind of ongoing scorecard, covering everything from the timeliness and accuracy of charge entries to the number of infusions per nurse per day.

It's one way to catch someone doing great work, but great work needs to be acknowledged as quickly as possible, Hennessy stresses. A lightning-fast e-mail is his frequent method for sending compliments. In fact, Hennessy is so fast that sometimes the recipient gets praised "in misspelled words." But expediency is everything, he says.

"I have two kids at home, and I know the benefits of immediate reinforcement." 


\section{How to Give Team Spirit One Big Single Boost}

How do you ignite team spirit? In one fell swoop, through a communitywide, employee-participating, headline-grabbing event, says John E. Hennessy, executive director of the Kansas City Cancer Center (KCCC) in Overland Park, Kansas.

This happens at his center every year in a big, splashy way-literally. In early October, at the beginning of Cancer Awareness Month, fountains in and around Kansas City gush pink, thanks to KCCC and a special rosy dye.

Employees seem as thrilled as the public. "They feel like 'Hey, that's us! We're out there,"' Hennessy says.

At Commonwealth Hematology Oncology (CHO), based in Quincy, Massachusetts, the occasion is Survivor Day, which started years back as a breast cancer support group. "We started long before anyone else was doing support groups-that group went for 10 years," Shuster says. "Each Christmas, we gathered at someone's home and celebrated life and friendship," she explains.

As the practice grew, the event also got bigger, and Survivor Day was officially born. Everyone got involved-from the front-desk people to the lab to the doctors and nurses, Shuster says. Now it's an annual highlight. Most recently, it was held at the JFK Library, where Scott Hamilton, a survivor of testicular cancer, gave the keynote address.

But it is the employee-wide involvement that makes it work and makes it a bonding experience. It is also a reminder that a high-functioning team effort takes good team players. "I need to recognize each and every one of them, from the receptionist to the lab person, my fellow nurses and nurse practitioners, and the doctors," she adds.

You don't have to be a kid to appreciate those benefits, concurs Shuster. "I know how good it feels when someone says, 'You made a difference."”

And therein lays another big reward-this one for managers. "People who feel needed as well as nurtured will go the extra mile for you," she explains.
Hennessy has proof of that extra-mile effort. The imaging facilities of KCCC clinched the American College of Radiology accreditation, and it took a "ton of extra work" and made KCCC a regional stand-out in the process, he says. But, he notes, on a smaller scale, exemplary work can include a new employee who strives to answer the phone after two rings instead of three, to a nurse practitioner who works to complete a research paper for presentation at the ASCO Annual Meeting.

Be aware that singling out employees for extra praise and attention can bring on a backlash, cautions Meryl Luallin of consulting firm Sullivan/Luallin Inc in San Diego, California. She says that a frequent complaint among employees in health care settings is that some supervisors "play favorites," and it can be a source of resentment. Her firm frequently surveys patients, staff members, referring physicians, and healthcare consumers.

Does the firm find it is true that some employees are rewarded more often? Well, yes and no. "There are perhaps some that do seem to get more plum assignments" or other forms of preferential treatment, she says.

However, in her experience, the boss isn't succumbing to those clever at currying favor. "The fact is that they (managers) go to the person who seems to be doing a better job, to the hard worker who is effective," she says.

These employees may get higher praise and more rewards, but by and large, they deserve it, she notes. In a medical environment, the stakes are high and time is precious. "You appreciate those you can rely on," she says.

That is one reason Hennessy depends on the "snow-day" rule, he says.

Too much reward can cause these acts of recognition to lose value. "You don't celebrate that everybody is doing what they are supposed to be doing," he says, instead, use the "snowday" perspective: Don't go overboard for a job well-done by somebody unless that somebody did it on a snow day, or under similar, hassle-loaded circumstances.

DOI: 10.1200/JOP.0725501 